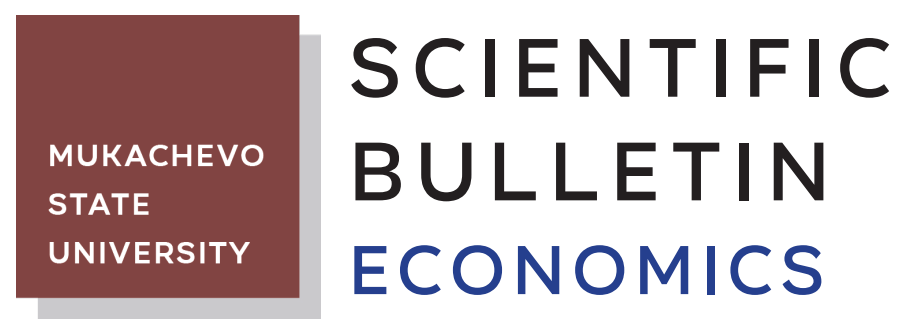

Volume 8, No. 2, 45-55

Journal homepage: https://economics-msu.com.ua/en

\title{
Public-Private Partnership in Healthcare and Pharmaceutical Sector of the Republic of Kazakhstan
}

\author{
Mansur Badaev ${ }^{\star}$ \\ Kazakh University of Economics, Finance and International Trade \\ 010000, 7 Zhubanov Str., Nur-Sultan, Republic of Kazakhstan
}

\begin{abstract}
Interaction between the state and business is one of the main ways to solve the social problems of modern states. The relevance of the subject matter is conditioned by the fact that the development of forms of public-private partnership provides an influx of investments from private entrepreneurs in the field of healthcare and pharmaceuticals in the Republic of Kazakhstan. The purpose of the study is to define the public-private partnerships and analyse international experience in implementing practises on specific projects. The methodological basis of the study consisted of the following methods: system, structural and functional, institutional, monographic, forecasting, tabular and graphical. In the course of the study, the theory and practise of public-private partnership in the healthcare and pharmaceutical sectors, the signs and principles of such partnership were considered. The classification was carried out, the most striking examples of the implementation of public-private partnerships were analysed. The differences between public-private partnership contracts were investigated, and attention was paid to the functions and content of such contracts, including the terms and expected risks. The advantages for each of the stakeholders in the public-private partnership were analysed: the private sector, the public sector, and consumers. The analysis of the current state of public-private partnership in the field of healthcare and pharmaceuticals in the Republic of Kazakhstan was carried out. The practical significance of the study lies in the development of recommendations for improving the forms of public-private partnership for the authorities to maintain state control and comply with the conditions for an adequate distribution of all risks, responsibilities and benefits among the participants of this type of partnership
\end{abstract}

Keywords: public-private partnership, pharmaceutical industry, partnership of the state and business, social sphere, PPP in healthcare

Received: 23.02.2021, Revised: 15.04.2021, Accepted: 18.06.2021

Suggested Citation: Badaev, M. (2021). Public-private partnership in healthcare and pharmaceutical sector of the Republic of Kazakhstan. Scientific Bulletin of Mukachevo State University. Series "Economics”, 8(2), 45-55. 


\section{Introduction}

The concept "public-private partnership" (PPP) and "private-public partnership" may have different connotations associated with emphasising the status of the parties to the partnership. In the first case, the primary role belongs to the state in interaction with other economic actors of the market. In the second case, the equivalent status is granted to public organisations of various fields of activity. The term public-private partnership better correlates with European law and the content of the concept "public administration" as a system of public authorities that, in exercising their powers, carry out public administration exclusively in the public interest. An important aspect of this concept is its connection with the integration of public administration institutions, civil society, and the private sector for the development of social community service projects [1].

The detailed content of the concept of PPP is contained in the "UN Millennium Declaration" of 2000 [2] and in the doctrine of the "Monterrey Consensus" of 2002 [3]. These documents state that PPPs are measures of public infrastructure aimed at sustainable development, through project financing and implementation using private investment and on the terms of transferring risks from the public sector to the private sector. In the United States, the term "public-private partnership" (PPP) is mainly used as a denotation of joint state and private financing of educational programmes, public utilities, urban renewal, territorial infrastructure development, and social services [4]. A.M. Abdel-Aziz and A.D. Russell in their paper [4] developed the structure of state requirements in the "publicprivate partnership". According to this structure, the main components of the partnership are rights, obligations, and responsibilities. For the successful implementation of the "public-private partnership", it is necessary to define specific state requirements, which will significantly reduce energy and economic resources [4].

Public-private partnerships are arrangements between public and private sector enterprises to provide public infrastructure, utilities, and related services. Such partnerships are characterised by the distribution of investments, risks, responsibilities, and rewards among the partners. The reasons for creating such partnerships are very different, but mostly they include the financing, design, construction, operation, and maintenance of public infrastructure and services. An important conclusion, from the standpoint of the institutional approach, is that without state-owned enterprises (that is, public property), the PPP mechanism itself becomes impossible [5]. M.A. Vasilenko, N.A. Drozdov, Yu.A. Tagiltseva, E.L. Kuzina, M.A. Kuzina studied public-private partnership through the prism of a system approach [5]. Thus, in the Western countries, two terms are used to denote the PPP mechanism. Its essence is understood as a process that is based on the combination of financial, labour, intellectual and other resources of the state and business for the joint implementation of projects.

Notably, the use of the phrase "public-private partnership" in the law, in which "public" is in the first place, is not accidental. This indicates that the state is the initiator of the relationship, that the implementation of its interests has priority over the private structures. PPP is designed to increase the competitiveness of the public sector of the national economy, attract investment to the economy for the development of an extensive infrastructure of a settlement, city or region. This observation reflects an important aspect necessary for understanding the use of the term "privatepublic partnership", which also has a rational and logical explanation for the fact that in this case, the private party has priority [6].

V.I. Borshch, I.I. Maslennikov, V.I. Truba, L.M. Tokarchuk considered public-private partnership as a progressive form of innovation and investment mechanism in the health sector of Ukraine, taking into account the international experience of the USA, Great Britain, Canada, and other countries. The main principles of work and criteria for assessing the effectiveness of public-private partnerships were defined [6].

The purpose of the study is to analyse public-private partnership as an effective tool for attracting investments in the healthcare and pharmaceutical sectors of the Republic of Kazakhstan. The implementation of the stated objective is determined by a number of tasks: 1) to describe the essence of the concept "public-private partnership"; 2) to consider the main features and principles of PPP; 3) to determine the classification of public-private partnership, its advantages; 4) to analyse the international experience of the introduction of PPP in the health sector; 5) to elaborate recommendations for improving public-private partnership in the health sector in the Republic of Kazakhstan.

\section{Literature Review}

The adoption of the law on PPP was an absolute achievement for the Republic of Kazakhstan [7], which significantly accelerated the study of various issues of PPP: legal aspects of PPP; scientific definition of PPP and its features in the context of Kazakhstan; clarification of the influence of internal and external factors on PPP. The greatest attention was paid to this issue by scientists-economists [8]. The economic content of the concept of PPP was also considered [9]. On this basis, the priority for this study is the issues of public management related to the institutional aspects of PPP.

Public management practise demonstrates the gradual improvement of the economic, political and ideological institutions of society [10]. It is an indisputable fact that they are interconnected and interdependent. Their state is not always predictable, especially in the conditions of the modern globalising world, which is dependent on general economic crises. This dependence gives grounds for asserting that it is economic institutions that are decisive in the hierarchy of social institutions [11]. They are considered the basis of social harmony and justice, democracy, and freedom of people. Therefore, the latter primarily become the object and subject of both scientific and political discussions [12]. As a rule, ideological institutions are regarded as 
secondary ones [13]. At the same time, the consequences of the functioning of the free market often need to eliminate the contradiction between the interests of public (state and municipal) and private owners. Market regulation is a function of the state [14]. But the state will only do this if its ideological institutions are focused on a balanced partnership with business [15]. This study searches for the criteria of balance between the economic, political, and ideological aspects of the institutional mechanism of PPP.

Scientific papers that cover PPP often rely on the documents adopted by the Commission of the European Community, the Directorate General of the European Commission for Regional Policy, as well as the UN European Commission (hereinafter referred to as the UN EC) for Europe [16]. These materials contain a description of the so-called international non-regulatory standards for creating a national organisational and legal framework, regulating the forms, methods that define the main criteria for creating a PPP infrastructure, and the principles of "good governance" in the field of PPP activities [17].

International standards affect the regulation of PPPs both at the level of domestic law (harmonisation and unification) and at the level of international law (codification). As a result, the legal space of PPP is unified [18]. In fact, common international approaches to PPP are being implemented in different countries. Some researchers define PPP with reference to international standards: publicprivate partnership is an institutionalised interaction of the public and private sectors in the economic sphere based on international norms and national legislation. Its purpose is to meet a specific public need, where the main partner is the state, which assumes responsibility to society and the key risk of possible non-implementation or improper implementation of the project [19].

\section{Materials and Methods}

The main source base of the study is international PPP standards [20]. They contain: methodology and principles of effective management in the field of PPP; conceptual approaches to take into account the interests of the state and business in the implementation of PPP projects; description of the recommended organisational and legal forms of partnership and justification for their application in a particular industry; recommendations on the financing model, the most rational distribution of risks between the state and the private partner; basic approaches to improving the regulatory framework; basic approaches to the tender procedure in the framework of PPP, and so on. International PPP standards are now widely distributed throughout the post-Soviet space through a large number of papers, methodological recommendations, and manuals.

International practise allows using the term PPP in a broad and narrow sense. To understand the pragmatics of this phenomenon, it is necessary to identify several approaches that are of practical importance. The derivation of the main provisions was based on the findings of studies [21-25]. The first approach implies that PPP is any use of business resources (capital, management experience, new technologies, innovations, know-how, etc.) to create a public good [21]. In this case, it refers to any official constructive interaction between public authorities and business in various spheres of public life - in the economy, education, and science. The structure of such interaction may include forms of medium - and long-term cooperation between public authorities and business [22-24]. In the second approach, PPP is usually understood as the interaction of business and state in the process of implementing projects of national or local significance. Sometimes, in a narrow sense, PPPs can be understood as cooperation on investments aimed at supporting innovative projects at the national, regional and local levels, in which partners pool resources and share responsibilities, risks and benefits [25].

The study of PPP is based on the system and structural-functional approaches, which were used to analyse the problems of relations between the state and business, the mechanisms for coordinating the economic interests of the main market participants and the state. Relying on international sources and international experience of PPP, this study combined the system and structural-functional approaches with concepts of economic theory, the norms of constitutional, administrative, and municipal law. With the help of the institutional approach, the relationship between the private entrepreneur and the state are studied. The use of the monographic method allows identifying and analysing PPP practises in the healthcare sector in European countries. The forecasting allows developing recommendations for improving PPP in the healthcare sector in the Republic of Kazakhstan. The graphical and tabular methods help to structure the collected material for visual display of the findings.

\section{Results and Discussion Public-private partnership: General meaning and principles}

Drawing attention to the already established practise of applying the term PPP, the concept "public-private partnership" in the Ukrainian literature in translation acquires various interpretations as "public-private collaboration", "private-public partnership", in some cases "municipal-private partnership". The concept "public-private partnership" (PPP) is the most adequate for displaying the general content of the concept of interaction between the state, local selfgovernment, the public sector and business at various levels of the territorial organisation of power. This approach expands the idea of public partners in relation to the existing approach implemented in the current legislation of the Republic of Kazakhstan [7]. In addition to the state and other public legal organisations, the author includes public law legal entities, namely: state scientific institutions and organisations, higher educational institutions of state and municipal ownership.

All variants of the phrase "public-private collaboration", "private-public partnership", "municipal-private partnership" are acceptable. If there is a need to reflect the 
institutional participants of PPP, the researcher can apply any variant of the phrase to denote this phenomenon without losing scientific correctness. In general, the terms "publicprivate partnership" and "municipal-private partnership" can be used as synonyms in some cases, if there is no need to detail the institutional status of the partner. However, in any case, it should be borne in mind that the concept "public-private partnership" is generic in relation to the concept "municipal-private partnership".

It is the institutional paradigm that claims to cover all possible aspects of the PPP problem, reducing them to the institutional basis from which organisational, political, legal, economic and any other mechanisms of interaction between the state and business are built. This thesis is an argument in favor of applying the institutional paradigm to solve the tasks set in this study. It provides an opportunity to study the phenomenon of PPP in dynamics, including the fact of imperfect organisational and legal support in the context of constant institutional changes and transformations. The available research results mentioned above do not answer the question of why PPP in the Republic of Kazakhstan is an uncompetitive mechanism for cooperation between public administration and business. Institutional factors, such as mutual distrust between business and the state, the lack of a positive public position on the transfer of ownership and disposal of state and municipal property to the private sector, also have a significant negative impact on the implementation of PPP and the effectiveness of its functioning. The main features of PPP include contractual relations, limited time, limited space (Fig. 1).
Time constraints, since the contract provides

for a specific facility that needs to be built or operated for a certain period of time

Figure 1. General features of public-private partnership

The international standards also formulate the main features of PPP, which must be taken into account to distinguish PPP from other forms of interaction between the state and business. In the EU Green Paper on PublicPrivate Partnerships and joint legislation on Public Contracts and Concessions, the main characteristics of PPPs include the following:

- relatively long-term cooperation between the private and public sectors;

- the existence of a number of agreements between different participants of cooperation on the method of project financing;

- defining the roles of the economic actors involved in the different stages of the project (design, completion, implementation, financing);

- the distribution of risks between public and private partners, according to which all the risks of the public sector can be transferred to the latter [20].

Notably, these features are also contained in the law of the Republic of Kazakhstan on public-private partnership [7]. Specifying the characteristic features of PPP, attention will be paid to such regulations, fixed in this law:

- established terms of partnership agreements (projects are usually developed for a specific object, which must be completed within the established time limit;

- cooperation is carried out on a voluntary and contractual basis (the private sector cannot be forced to agree);

- specific forms of distribution of responsibility between partners (the state determines the positions of public interests, cost and quality parameters, monitors the implementation of projects, and the private partner takes on the tasks of operational activities at different stages of the project - development, financing, construction and operation, management, practical implementation of services to consumers;

- specific forms of project financing (the project is financed by private investments supplemented by public financial resources, or by joint investment of several participants);

- risk sharing between the parties to the agreement on the basis of relevant agreements;

- specific forms of distribution of responsibility between partners: the state determines the project objectives from the standpoint of the interests of society and regulates the cost and quality parameters, monitors the implementation of projects;

- the state exercises the function of controlling the activities of the private sector in the management of state property.

As a tool of economic policy, PPP assumes that a thorough consideration of possible risks will be carried out, and they will be distributed among all participants of the PPP. Each party in a PPP is interested in the benefits. The feasibility of using PPP is determined by the most efficient spending of funds in comparison with conventional schemes. PPP is based on the following principles (Fig. 2): 


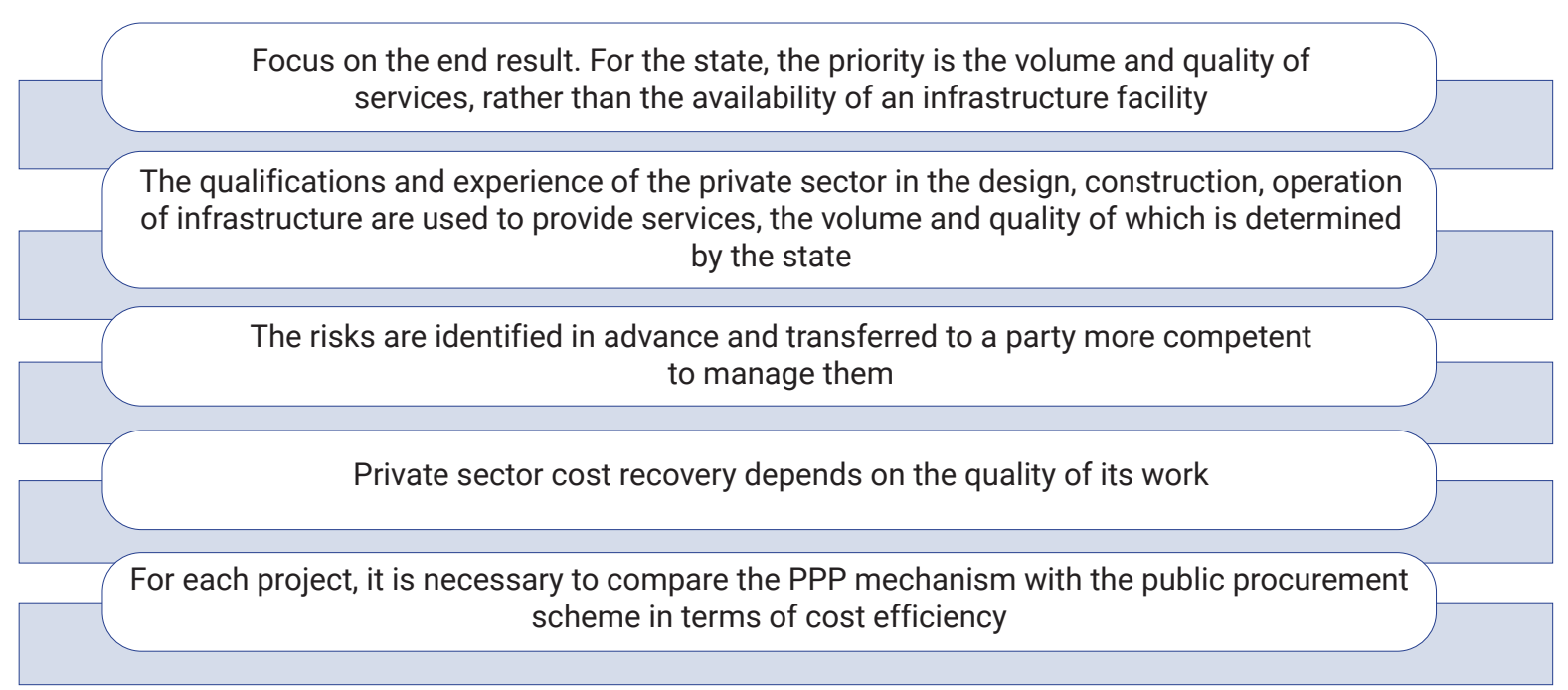

Figure 2. Principles of building relationships in PPP

Next, the study considers each principle separately. Focus on the end result (services). Under the conventional financing scheme, the operator imposes requirements on the private contractor/supplier in terms of volume, timing, quality, and so on. In PPP, the state imposes a requirement for the provision of final services that are based on taking into account the consumer interests. The dependence of cost recovery on the quality of services provided. The operator of a PPP is the private sector, so the quality of services depends on it. The terms of the PPP contract ensure the operator's interest in the final result, since it reimburses its costs from the revenue received from the provision of services, or remuneration. In order to avoid reducing the operator's interest in the final result, state support should not be excessive.

Risk-benefit sharing. The transfer of some functions to the private sector does not mean the self-exclusion of the public sector. PPP provides for a thorough study and identification of possible risks, describing them in the Feasibility report. Possible risks are distributed among the project parties, and the party that will best cope covers the possible risk. The benefits of participating in the project are distributed accordingly. When developing PPP projects, the viability cycle of the future facility is taken into account, since the private sector must be confident of recovering costs and making a profit in the long run. The use of PPP is not an end in itself. The main thing is the efficiency of spending compared to the traditional approach. The form of the PPP determines what functions and risks the private sector assumes, and the duration of the PPP contract depends on the level of risks and obligations assumed. It should be noted that in the World Bank classification, “... a form of cooperation between the public and private sectors, in which all risks and responsibilities are assigned to one of the parties, is not a PPP" [26]. These types of cooperation include, for example, service contracts, in which the risks are almost completely covered by the state, as well as privatisation contracts, in which the risks are covered by the private sector.

\section{Classification of the main models of interaction in PPP}

Conventionally, all PPPs encountered in practise can be divided into three main groups (Fig. 3):

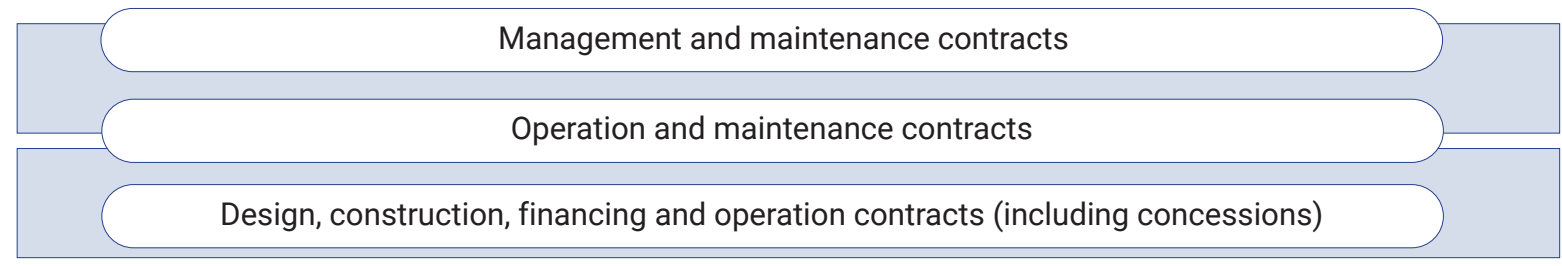

Figure 3. Classification of PPP forms

Management and maintenance contracts are those in which private sector entities perform functions for the management and maintenance of state-owned facilities, make administrative decisions in the current production and operational activities. Under these contracts, there is no implementation of institutional changes to the facility.
The main goal of such contracts is to improve the internal management system and operational activities of the facility. For their management and maintenance services, private sector entities receive remuneration, which is determined during the competition. In most cases, the contract is given to the company that offered a more reasonable price for the 
services. Notably, the actual payment of remuneration is tied to pre-defined performance indicators. Another feature of such contracts is that the public sector retains overall responsibility for the provision of services to consumers. The public sector is also responsible for the expansion, rehabilitation and major repairs of the facilities. Usually, such contracts are concluded for 3-5 years with minimal risks.

Operating and maintenance contracts are those in which production facilities are leased to the private sector. The private sector in this case performs the function of the operator, and is responsible to the consumer. When concluding such contracts, the goal is to increase operational efficiency, improve the quality of services provided, and attract funds from the private sector to finance the facility. The most common type of such contract is leasing: a private operator, depending on its performance indicators, receives remuneration for the operation and maintenance of the facility. On the other hand, the private operator pays the government a fee that is used for capital investments. The average duration of such PPP contracts is 7-10 years with medium risks.

Contracts for design and construction. In this case, the private sector assumes responsibility for the provision of all related services, which may include, for example, payment collection and public relations management. The public sector remains only a regulator. The main goal in this case is to reduce the costs and risks of the public sector, improve the quality of services, and expand opportunities for infrastructure development. An important aspect of concession contracts is the dependence of the amount of cost recovery of the concessionaire on the quality of the services provided by it, which are determined by the performance indicators of its activities. Concession contracts are usually concluded for a period of 20-30 years, the degree of risk of which is high. PPP implies a partnership between the state and the private sector and in the sharing of benefits and risks. The benefits for each of the stakeholders are clearly outlined in Figure 4.

Benefits for the public sector

- Infrastructure development at an accelerated pace and the possibility of providing better quality services;

- Attracting funds and the experience of the private sector in the field of investment management;

- Transfer of technology and know-how;

- Transfer of part of the risks to the private sector;

- Efficient management of the private sector facility;

- Better distribution of budget funds;

- Development of local capital markets and the banking industry;

- Attracting private and international investments;

- Control over service management and infrastructure quality;

- The possibility of projecting the experience of private companies in the field of creating infrastructure facilities on other similar facilities that require funding from public sources

\section{Benefits for the private sector}

Benefits for the consumer

- Opening of a market formerly owned by the public sector;

- New investment opportunities and, accordingly, new sources of income;

- Sharing of risks with the state;

- The possibility of off-balance sheet operations;

- The possibility of obtaining an acceptable rate of return;

- Gaining experience in managing large projects;

- Growth of the image in the market

$$
\text { ard }
$$


per 1.5 million people) [27]. Thus, the Comprehensive Plan to Combat Cancer for 2018-2022 includes four areas:

- prevention and management of risk factors;

- development of highly effective early diagnosis;

- implementation of an integrated model for providing cancer care;

- development of human resources and science [28].

The main part of the equipment for the development of cancer services in the regions was purchased under the PPP. In 2019, the Republic of Kazakhstan began conducting molecular genetic research within the framework of the GOBMP (Guaranteed Amount of Free Medical Care), additional funding in the amount of 1.6 billion KZT was allocated for almost 100 thousand patients. CT (Computed tomography) and MRI (Magnetic resonance imaging) examinations in patients with suspected cancer. These measures will increase the diagnosis of early stages to 33\% by 2022 . The installation of PAX systems in 18 regions of the country was carried out within the framework of PPP projects.

PPP is actively developing in the North Kazakhstan and Turkestan regions. Thus, the akims of these regions signed PPP agreements with the Turkish company "YDA Holding" for the construction of large modern hospitals with a capacity of 500 beds [29]. The long-term plan for the development of healthcare infrastructure until 2025 determines the need for investments in healthcare of more than 1 trillion $\mathrm{KZT}$, the main share of which is occupied by projects for the construction of 17 large multi-specialty hospitals. Six projects - priority ones:

1) united Uuniversity hospital with 1200 beds in Almaty at the Kazakh National Medical University named after S. Asfendiyarov;

2) multidisciplinary hospital with 300 beds in Almaty at the Kazakh National Medical University named after S. Asfendiyarov;

3) multi-specialty hospital with 300 beds in Karaganda Medical University;

4) multi-specialty hospital with 500 beds in Nur-Sultan;

5) multidisciplinary regional hospital with 500 beds in Petropavlovsk;

6) multi-specialty hospital with 600 beds in Turkestan.

These facilities are planned to be implemented under the PPP infrastructure model. The appearance of new high-quality and modernised hospitals will have a positive impact on the development of incoming medical tourism and will reduce the number of citizens travelling abroad for treatment [30].

As for pharmaceutical production, it is necessary to note the peculiarity of the national market: the growth dynamics over the past two years shows that the contribution of the pharmaceutical industry to the country's GDP is quite low due to the weak market base. In 2018, the pharmaceutical industry accounted for no more than $0.1 \%$ of GDP. Kazakhstan's pharmaceutical industry is significantly inferior in gross profitability to foreign companies, which occupy a dominant position due to the low technological and production capabilities of the local manufacturer. Today, the share of foreign products sold in the retail market is about $70 \%$ [31]. Thus, in 2018, the volume of the world market of medicines amounted to 1.174 billion USD [32]. The market share of the EAEU (Eurasian Economic Union) is less than 2.6\%, and the share of Kazakhstan in the EAEU is $2.4 \%$ [33].

From 2010 to 2018,30 projects were implemented in the pharmaceutical industry within the framework of PPP, the volume of investments - 45 billion KZT. For example, the Karaganda pharmaceutical complex, introduced as part of the industrialisation map, has been increasing the production of medicines since 2018, expanding the range of pharmaceutical products from antibiotics of the cephalosporin group to drugs for the treatment of cancer. Currently, there are 168 pharmaceutical enterprises operating in the Republic of Kazakhstan, of which 3 are large, 11 are medium-sized, and 154 are small. As part of the PPP, investors from Poland, Turkey, China and Russia have been attracted to the industry. According to the results of the first five-year plan, 24 new projects worth 28.8 billion KZT were implemented in the pharmaceutical industry with the creation of more than 3,000 permanent jobs. The most significant projects in this industry:

- increase in the production capacity of JSC "Himfarm" (Shymkent);

- modernisation of the pharmaceutical factory (Almaty);

- construction of the pharmaceutical plant "ELEAS" (Almaty Region);

- construction of the pharmaceutical plant "Sultan" LLP (Almaty region);

- expansion of the existing production with an increase in the range in accordance with the international standard ISO 13485-2003 “Merusar \& K” LLP (Pavlodar Region) [34]. Unfortunately, according to the results of the first half of 2019, there is a sharp decline in investment in healthcare (Fig. 5). Thus, from January to May, investments decreased by $15 \%$. Until 2018, such a reduction was observed annually, so in 2016, the decrease was $19.7 \%$. However, in the first half of 2018, there was a record increase of $62 \%$ (Fig. 6).

This is conditioned by the attraction of private investment in solving problems with the wear and tear of buildings of medical organisations in the amount of 7.5 billion KZT for the construction of 67 medical facilities, and the construction of 165 medical buildings in 2018 [36]. The main reason for the decrease in the amount of investments in 2019 was a reduction in the investment of business' own funds, a decrease in infusions from local budgets. At the same time, banks' interest in the healthcare sector has significantly increased, as investments from borrowed funds and bank loans have increased 5.2 times over the year (Fig. 7). 


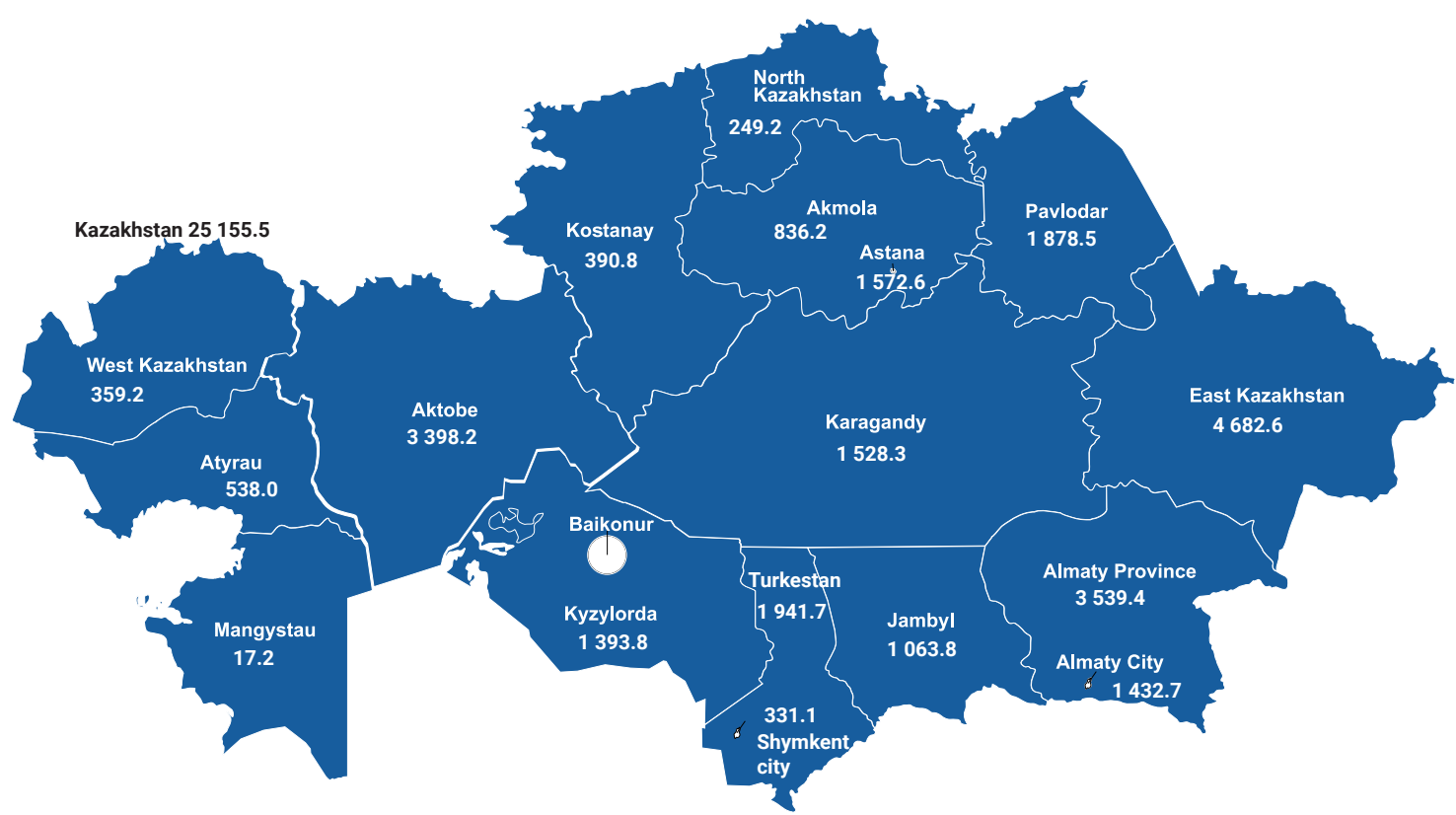

Figure 5. Investments in healthcare and social services in the Republic of Kazakhstan for the first half of 2019 Source: [35]

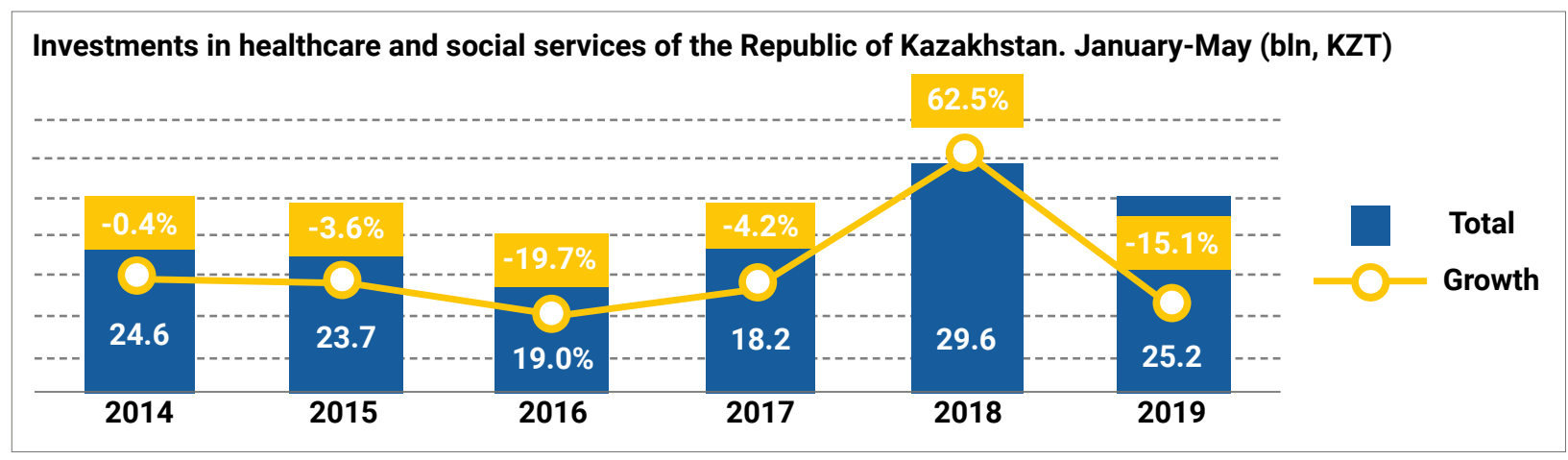

Figure 6. Investments in healthcare and social services in the Republic of Kazakhstan for the first half of 2014-2019 Source: [35]

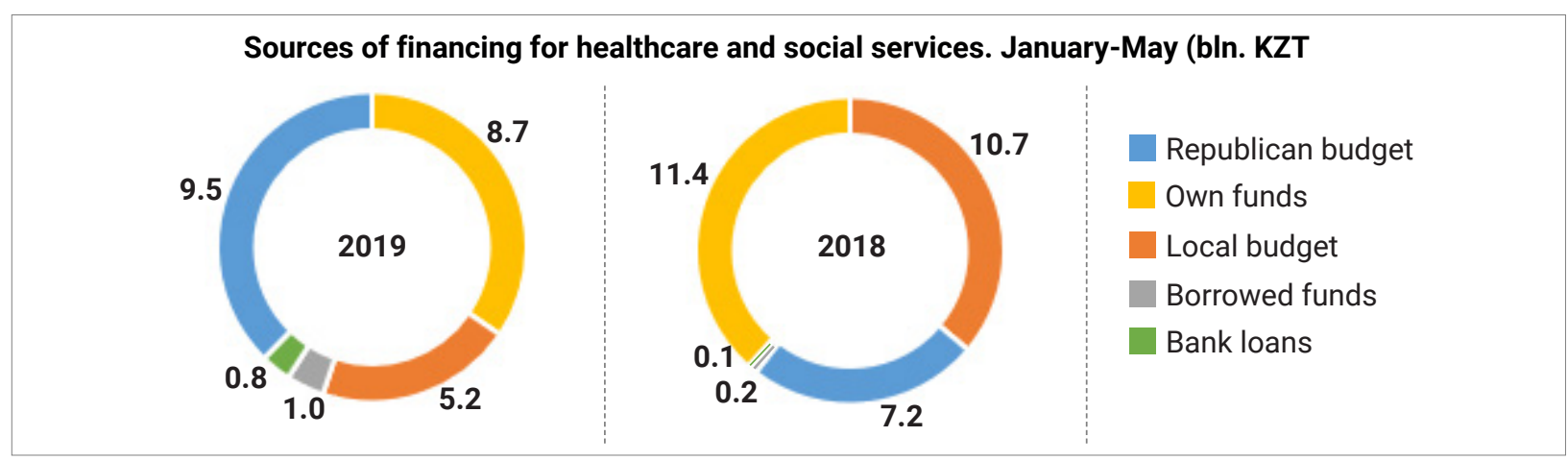

Figure 7. Sources of financing of healthcare and social services in the Republic of Kazakhstan for the first half of 2019 Source: [35]

According to the Minister of Health E.A. Birtanov, by 2021 it is planned to build more than 600 PHC facilities (primary healthcare) and hospitals within the framework of PPP in order to cover all rural settlements with medical services [35]. The development of the investment policy of the healthcare system of the Republic of Kazakhstan will eventually allow:

- improving the key performance indicators of the healthcare system;

- modernising the financing of the industry;

- reducing the industry's budget deficit;

- improving the quality, accessibility, and satisfaction of the population with medical services;

- improving the social status of healthcare workers;

- implementing the strategic objectives of the industry.

Only with a comprehensive solution to the problems 
of reducing risks and increasing profitability in the healthcare system can the desired result be achieved.

\section{Recommendations for improving PPP in the healthcare sector}

Based on the study of the theory and practise of PPP in Kazakhstan's healthcare, the following recommendations were developed:

- designate the special status of the sphere of medical services as a socially significant sector of the economy, and to resolve the issue of creating under the auspices of the Government (the Ministry of National Economy of the Republic of Kazakhstan, the Ministry of Health, the Ministry of Labour, Employment and Social Protection of the Population) a state operator for the development of the investment policy of the health system of the Republic of Kazakhstan;

- redefine the healthcare industry as an effective investment vehicle. the healthcare system should become attractive for investment;

- strengthen the competitive environment in the industry, develop the private sector, develop a new economic mechanism for healthcare facilities, including: decentralise the financing of the industry, improve the quality of medical services provided, increase public satisfaction and access to medical care, improve human capital, expand the innovation and scientific environment, introduce corporate governance principles, improve the regulatory framework;

- increase profitability by providing state benefits and tax preferences in investment projects, since investments in healthcare are investments in the human potential of the country.

In the medical field, it is possible to introduce new and expand the range of PPP types used (Table 1).

Table 1. Forms of introduction of new and expansion of the range of types of PPP

\section{Type of PPP}

PPP based on a contract in the field of medical equipment supply

\section{Scale}

Positive aspects

Systematisation of information about the capabilities of medical equipment, centralisation of knowledge and training

Regional and resources on the effective operation of equipment, guarantee national of service and repair, reduction of the cost of components and consumables, exclusion of cases of unfair treatment on the part of suppliers - "shell companies"

Transfer of functions to search for information about the availability and cost of medicines, minimisation of forced

PPP on the basis of a contract in the field of drug supply
Region or

medical

institution contacts with numerous potential suppliers, optimisation of structures that carry out public procurement, reduction of risks in budget planning

PPP based on a contract in the field of social patronage

PHC Centre

Reallocation of secondary functions, fulfillment of the potential of the medical worker

PPP based on a concession for the construction of new healthcare facilities

Region

Risk sharing for construction, postponement of payments for the construction of the facility, implementation of payments by placing a state order, introduction of new management technologies and competitiveness of the new institution

PPP on the basis of a concession in the Regional and Reduce public sector costs and risks, expand infrastructure field of trust management of state assets national development opportunities

Thus, the current state of the economy of the Republic of Kazakhstan is characterised by the consolidation of the efforts of the state and the private sector in the search for new forms and methods of creating, managing, and regulating infrastructure. PPP is a real mechanism for interaction between the public sector and private capital in the creation, modernisation, maintenance, and operation of infrastructure facilities.

This provision fully applies to healthcare. The nature of self-financing of such projects makes them attractive to investors. Summarising international experience and analysing best practises allows forming specific proposals for the further development of PPP in Kazakhstan's healthcare sector, including attracting foreign companies to provide concessions in the field of medical and pharmaceutical infrastructure, including:

1) expanding the scope and mechanisms of PPP;

2) improving the regulatory framework for PPP;

3) developing the methodological base;
4) strengthening the capacity of public authorities in the field of PPP.

\section{Conclusions}

In the course of the study, PPP was analysed as a tool for attracting investment to the national economy. Based on this, a review of the literature is conducted and several positions on the definition of the concept of PPP are considered. According to this, PPP should be perceived in two contexts. The first is the common use of business resources of two entities - the state and the individual. In the second - the implementation of specific projects on the terms of PPP. Public-private partnership has different formulations: "public-private partnership", "private-public partnership" and others, which are similar in their main content and reflect the participants in this process. The main features and principles of PPP are highlighted. Among the signs of PPP, the main ones are contractual relations, limited time and space. The principles of PPP 
include: focus on the final result, the dependence of cost recovery on the quality of services provided, the separation of risks and benefits.

The classification of the main forms of public-private partnership is carried out and the most common ones are identified: management and maintenance contracts, operation and maintenance contracts, design, construction, financing and operation contracts, and concessions. The international experience of PPP practise in the Republic of
Kazakhstan in the field of healthcare and pharmaceuticals is analysed. The main results of the implemented projects in the above-mentioned areas are considered. However, the level of investment is not high enough, which requires the development of additional motivation for individuals to invest in the healthcare sector. Recommendations on the creation of new and modernisation of existing forms of PPP in the field of healthcare and pharmaceuticals in the Republic of Kazakhstan have been developed.

\section{References}

[1] Imtiaz, A., Farooq, G., Haq, Z.U., Ahmed, A., \& Anwar, S. (2017). Public private partnership and utilization of maternal and child health services in district Abbottabad, Pakista. Journal of Ayub Medical College Abbottabad, 29(2), $275-279$.

[2] General Assembly Resolution No. 55/2 “United Nations Millennium Declaration.” (2000, August). Retrieved from https://www.un.org/ru/documents/decl_conv/declarations/summitdecl.shtml.

[3] Monterrey Consensus of the International Conference on Financing for Development. (2002). Retrieved from https://www.un.org/ru/documents/decl_conv/declarations/monterrey.shtml.

[4] Abdel-Aziz, A.M., \& Russell, A.D. (2001). A structure for government requirements in public-private partnerships. Canadian Journal of Civil Engineering, 28(6), 891-909. doi: 10.1139/L01-058.

[5] Vasilenko, M.A., Drozdov, N.A., Tagiltseva, J.A., Kuzina, E.L., \& Kuzina, M.A. (2017). Systematic approach and advanced marketing in public-private partnerships. In Proceedings of the 2017 International Conference "Quality Management, Transport and Information Security, Information Technologies” (IT\&QM\&IS) (pp. 27-31). St. Petersburg: IEEE. doi: 10.1109/ITMQIS.2017.8085753.

[6] Borshch, V.I., Maslennikov, Y.I., Truba, V.I., \& Tokarchuk, L.M. (2019). Public-private partnership as an investment and innovation tool for medical facilities: A case of Ukrainian healthcare. Wiadomosci Lekarskie, 72(11 cz 1), $2155-2160$.

[7] Law of the Republic of Kazakhstan No. 379-V “On public-private partnership". (2015, October). Retrieved from https://online.zakon.kz/document/?doc_id=37704720.

[8] Orlov, A. (2018). Particularities of public-private partnership mechanisms application for implementation of construction megaprojects of transport infrastructure development. Advances in Intelligent Systems and Computing, 692, 282-288. doi: 10.1007/978-3-319-70987-1_30.

[9] Chen, Y.-W. (2005). Public-private partnership in urban development: The experience of the Netherlands. In Proceedings of CRIOCM 2005 International Research Symposium on Advancement of Construction Management and Real Estate (pp. 220-232). Hong Kong: The Chinese Research Institute of Construction Management.

[10] Statsenko, I.M. (2018). Economic preconditions for the development of public-private partnership in the Vologda region. Economy of Region, 14(3), 927-940. doi: 10.17059/2018-3-17.

[11] Hellowell, M. (2016). The price of certainty: Benefits and costs of public-private partnerships for healthcare infrastructure and related services. Health Services Management Research, 29(1-2), 35-39. doi: 10.1177/0951484816639742.

[12] Sadeghi, A., Barati, O., Bastani, P., Jafari, D.D., \& Etemadian, M. (2016). Experiences of selected countries in the use of public-private partnership in hospital services provision. Journal of the Pakistan Medical Association, 66(11), $1401-1406$.

[13] Abubakirov, A.S., Zudin, A.B., \& Snegireva, Y.Y. (2019). The public-private partnership in medical services market. Problemy Sotsial'noi Gigieny, Zdravookhraneniia i Istorii Meditsiny, 27(6), 953-958. doi: 10.32687/0869-866X-201927-6-953-958.

[14] Luijten, P.R., Van Dongen, G.A.M.S., Moonen, C.T., Storm, G., \& Crommelin, D.J.A. (2012). Public-private partnerships in translational medicine: Concepts and practical examples. Journal of Controlled Release, 161(2), 416-421. doi: 10.1016/j.jconrel.2012.03.012.

[15] Himmel, M., \& Siemiatycki, M. (2017). Infrastructure public-private partnerships as drivers of innovation? Lessons from Ontario, Canada. Environment and Planning C: Politics and Space, 35(5), 746-764. doi: 10.1177/2399654417701430.

[16] Goldstein, B.T., \& Mele, C. (2016). Governance within public-private partnerships and the politics of urban development. Space and Polity, 20(2), 194-211. doi: 10.1080/13562576.2016.1157968.

[17] Yang, T., Long, R., Cui, X., Zhu, D., \& Chen, H. (2017). Application of the public-private partnership model to urban sewage treatment. Journal of Cleaner Production, 142, 1065-1074. doi: 10.1016/j.jclepro.2016.04.152.

[18] Kostyak, L., Shaw, D.M., Elger, B., \& Annaheim, B. (2017). A means of improving public health in low- and middleincome countries? Benefits and challenges of international public-private partnerships. Public Health, 149, $120-129$. doi: 10.1016/j.puhe.2017.03.005.

[19] Marenjak, S., \& Kušljiè, D. (2009). Legal framework of public-private partnerships. Gradjevinar, 61(2), $137-145$.

[20] UNECE Standards for Health PPP Projects (n.d.). Retrieved from https://clck.ru/VDKW5.

[21] Liu, H.J., Love, P.E.D., Smith, J., Sing, M.C.P., \& Matthews, J. (2018). Evaluation of public-private partnerships: A life-cycle performance prism for ensuring value for money. Environment and Planning C: Politics and Space, 36(6), 1133-1153. doi: 10.1177/2399654417750879. 
[22] Ivashchenko, T.N., Mironenko, N.V., Popovicheva, N.E., \& Zhuravleva, T.A. (2017). Macro-economic models of implementation of public-private partnership: Experience, problems and perspectives. Advances in Intelligent Systems and Computing, 726, 609-619. doi: 10.1007/978-3-319-90835-9_71.

[23] Tastulekov, S.B., Shalbolova, U.Z., \& Satova, R.K. (2019). Public-private partnership formation in Kazakhstan. Academy of Strategic Management Journal, 18(5), 1-8.

[24] Ibem, E.O. (2011). The contribution of public-private partnerships (PPPs) to improving accessibility of lowincome earners to housing in southern Nigeria. Journal of Housing and the Built Environment, 26(2), $201-217$. doi: 10.1007/s10901-011-9213-1.

[25] Forsyth, T. (2005). Building deliberative public-private partnerships for waste management in Asia. Geoforum, 36(4), 429-439. doi: 10.1016/j.geoforum.2004.07.007.

[26] Birtanov, E.A. (2010). Organizational, methodological and financial and economic foundations of the innovation and investment strategy for the development of the health care system of the Republic of Kazakhstan (Doctoral thesis, Kazakhstan School of Public Health (SHO), Almaty, Republic of Kazakhstan).

[27] Additional 6 PET centers to be opened in Kazakhstan. (2019). Retrieved from http://pharmnews.kz/ru/news/vkazahstane-budut-otkryty-dopolnitelnye-6-pet-centrov_14958.

[28] Law of Republic of Kazakhstan No. 395 "On approval of the Comprehensive Plan to Combat Cancer in the Republic of Kazakhstan for 2018-2022”. (2018, June). Retrieved from http://adilet.zan.kz/rus/docs/P1800000395.

[29] New hospitals under PPP. (2019). Retrieved from http://pharmnews.kz/ru/news/novye-bolnicy-v-ramkah-gchp_15263.

[30] Saparbayev instructed to reduce the time frame for the implementation of PPP projects in healthcare. (2019). Retrieved from https://clck.ru/VDKcq.

[31] Production of pharmaceutical products in the EAEU in 2018. Express information. (2019). Retrieved from https://clck.ru/VDKdi.

[32] Panorama of the global pharmaceutical market. (2002). Retrieved from https://www.apteka.ua/article/33193.

[33] Healthcare and pharmaceuticals. (2021). Retrieved from https://newsline.kz/ru/section/640/.

[34] Over the past 4 years, the volume of production of pharmaceutical products in the Republic of Kazakhstan has doubled. (2019). Retrieved from https://clck.ru/VDKej.

[35] Investments in health and social services decreased by $15 \%$ in a year. (2019). Retrieved from http://pharmnews.kz/ru/ news/investicii-v-sferu-zdravoohraneniya-i-socialnyh-uslug-snizilis-na-15-za-god_15327.

[36] Official website of the Ministry of National Economy of the Republic of Kazakhstan Statistics Committee. (n.d.). Retrieved from https://economy.gov.kz/ru/kategorii/komitet-po-statistike.

\title{
Державно-приватне партнерство в охороні здоров'я та фармацевтичному секторі Республіки Казахстан \\ Мансур Бадаєв \\ Казахський університет економіки, фінансів та міжнародної торгівлі 010000, вул. Жубанова, 7, м. Нур-Султан, Республіка Казахстан
}

\begin{abstract}
Аннотация. Взаємодія держави та бізнесу є одним з основних шляхів вирішення соціальних проблем сучасних держав. Актуальність теми дослідження обумовлена тим, що розвиток форм державно-приватного партнерства забезпечує приплив інвестицій з боку приватних підприємців у сферу охорони здоров'я та фармацевтики в Республіці Казахстан. Метою статті є характеристика державно-приватного партнерства та аналіз міжнародного досвіду реалізації практик на конкретних проектах. Основною методологічною базою дослідження стали такі методи: системний, структурно-функціональний, інституціональний, монографічний, прогнозування, табличний і графічний. У процесі дослідження розглянуто теорію та практику державно-приватного партнерства у сфері охорони здоров'я та фармацевтичній сфері, ознаки та принципи такого партнерства. Проведено класифікацію, проаналізовано найбільш яскраві приклади реалізації державно-приватного партнерства. Досліджено відмінності між контрактами державно-приватного партнерства, звернуто увагу не тільки на функції і зміст таких договорів, але й на терміни, передбачувані ризики. Проаналізовано переваги для кожної із зацікавлених сторін у державноприватному партнерстві: приватний сектор, державний сектор, споживачі. Проведено аналіз сучасного стану державно-приватного партнерства в розглянутій сфері в Республіці Казахстан. Практична цінність дослідження полягає в розробці рекомендацій щодо поліпшення форм державно-приватного партнерства для органів влади з метою збереження контролю з боку держави і дотримання умов адекватного розподілу між учасниками такого виду партнерства всіх ризиків, відповідальності та вигод
\end{abstract}

Ключевые слова: публічно-приватне партнерство, фармацевтична галузь, партнерство держави та бізнесу, соціальна сфера, ДПП в охороні здоров'я 